\title{
Synthesis and Characterisation of Heterobimetallic Organotin(Iv) Glycolates Containing Aluminium
}

\author{
Nandu Bala Sharma, Anirudh Singh ${ }^{*}$ and Ram C. Mehrotra ${ }^{\dagger}$ \\ Department of Chemistry, University of Rajasthan, Jaipur - 302004, India.
}

\begin{abstract}
Interactions of $\mathrm{Al}\left(\mathrm{OPr}^{\prime}\right)_{3}$ with two equivalents of a variety of glycols $(\mathrm{HOGOH})$ yield homometallic glycolates $\mathrm{Al}(\mathrm{OGO})(\mathrm{OGOH})\left(\mathrm{G}=\mathrm{CMe}_{2} \mathrm{CH}_{2} \mathrm{CHMe}\right.$ (1), $\mathrm{CMe}_{2} \mathrm{CMe}_{2}$ (2), or $\mathrm{CMe}_{2} \mathrm{CH}_{2} \mathrm{CH}_{2} \mathrm{CMe}_{2}$ (3)) having one residual hydroxy group, which on reactions with $\mathrm{Bu}_{2} \mathrm{Sn}\left(\mathrm{OPr}^{i}\right)_{2}$ or $\mathrm{Bu}_{3} \mathrm{Sn}\left(\mathrm{OPr}^{\prime}\right)$ in $1: 1$ molar ratio afford heterobimetallic compounds of the general formulae $\mathrm{Al}(\mathrm{OGO})_{2} \mathrm{Bu}_{2} \mathrm{Sn}\left(\mathrm{OPr}^{\prime}\right)\left(\mathrm{G}=\mathrm{CMe}_{2} \mathrm{CH}_{2} \mathrm{CHMe}\right.$ (4), $\mathrm{CMe}_{2} \mathrm{CMe}_{2}(5), \mathrm{CMe}_{2} \mathrm{CH}_{2} \mathrm{CH}_{2} \mathrm{CMe}_{2}(6)$ ) and $\mathrm{Al}(\mathrm{OGO})_{2} \mathrm{Bu}_{3} \mathrm{Sn}\left(\mathrm{G}=\mathrm{CMe}_{2} \mathrm{CH}_{2} \mathrm{CHMe} \mathrm{(7),} \mathrm{CMe}_{2} \mathrm{CMe}_{2}(8)\right.$ ), respectively. All these derivatives have been characterised by elemental analyses, molecular weight measurements and spectroscopic (IR; NMR, ${ }^{1} \mathrm{H},{ }^{27} \mathrm{Al}$, and ${ }^{119} \mathrm{Sn}$ ) studies.
\end{abstract}

\section{INTRODUCTION}

In spite of some developments in the chemistry of homometallic glycolate derivatives of di- and tetravalent tin $/ 1-2 /$, the heterobimetallic glycolates based on organotin(IV) moieties appear not to have been investigated $/ 3$ / so far. We, therefore, report in this paper, for the first time, the synthesis and characterisation of heterobimetallic glycolate derivatives of organotin(IV) containing aluminium. The present study assumes additional significance because a heterobimetallic organotin(IV) derivative containing both a reactivity modifier /4/ glycolate group and a reactive alkoxide group(s) may prove a better precursor for the synthesis via sol-gel process of heterometal systems / I-3/ containing an organotin oxide and / or hydroxide moiety.

\section{MATERIALS AND METHODS}

Special precautions were taken to exclude moisture from the reaction apparatus, solvents, and reactants. Solvents such as benzene, isopropyl alcohol, $n$-hexane, and dichloromethane were purified and dried by

\footnotetext{
* Address correspondence to: Anirudh Singh

E-mail: <anirudhsinghunivjpr@yahoo.co.in> (A.S.

${ }^{\dagger}$ Deceased
} 
standard procedures $/ 5 / . \mathrm{Bu}_{2} \mathrm{Sn}\left(\mathrm{OPr}^{\prime}\right)_{2} / 6 /$ and $\mathrm{Bu}_{3} \mathrm{Sn}\left(\mathrm{OPr}^{\prime}\right) / 2 /$ were prepared by the literature methods. Aluminium isopropoxide was prepared $/ 7 /$ by the reaction of aluminium foils with isopropyl alcohol in the presence of a catalyst, $\mathrm{HgCl}_{2}$ or $\mathrm{I}_{2}$. Glycols: 2-methylpentane-2,4-diol (b.p. $198^{\circ} \mathrm{C} / 750 \mathrm{~mm}$ ); 2,3dimethylbutane-2,3-diol (b.p. $171^{\circ} \mathrm{C} / 750 \mathrm{~mm}$ ); and 2,5-dimethylhexane-2,5-diol (sublimation temp. $80^{\circ} \mathrm{C} / 0.1$ $\mathrm{mm}$ ) were dried and purified by refluxing over $\mathrm{Al}\left(\mathrm{OPr}^{1}\right)_{3}$, followed by distillation prior to use. Isopropyl alcohol in the azeotrope was determined /8-10/ oxidimetrically. Aluminium was determined $/ 11 /$ as oxinate, while tin was determined $/ 1 \mathrm{l} /$ as its oxide. Molecular weights were determined cryoscopically in benzene solution. ${ }^{1} \mathrm{H}(89.55 \mathrm{MHz}),{ }^{27} \mathrm{Al}(23.29 \mathrm{MHz})$, and ${ }^{119} \mathrm{Sn}(33.35 \mathrm{MHz}) \mathrm{NMR}$ were recorded in $\mathrm{CDCl}_{3}$ and $\mathrm{C}_{6} \mathrm{H}_{6}$ solutions on a JEOL FX 90Q spectrometer. IR spectra $\left(4000-200 \mathrm{~cm}^{-1}\right)$ were recorded as Nujol mulls on a Nicolet Magna 550 spectrophotometer. Carbon and hydrogen analyses were performed on a Perkin Elmer$2400 \mathrm{II}$ CHNS/O analyser.

\section{Preparation of glycolate derivatives}

Due to similarity in the synthetic procedures for the new homo- and heterobimetallic derivatives, only one typical synthesis of each class is described in detail for the sake of brevity, while preparative and analytical details of all the derivatives are summarized in Table $\mathbf{I}$.

\section{Preparation of $\mathrm{Al}\left(\mathrm{OCMe}_{2} \mathrm{CH}_{2} \mathrm{CHMeO}\right)\left(\mathrm{OCMe}_{2} \mathrm{CH}_{2} \mathrm{CHMeOH}\right)(1)$}

A benzene $(\sim 50 \mathrm{ml})$ solution containing $\mathrm{Al}\left(\mathrm{OPr}^{\mathrm{j}}\right)_{3}(2.42 \mathrm{~g}, 11.84 \mathrm{mmol})$ and $\mathrm{HOCMe}{ }_{2} \mathrm{CH}_{2} \mathrm{CHMeOH}$ $(2.80 \mathrm{~g}, 23.69 \mathrm{mmol})$ was refluxed under a fractionating column for $\sim 6 \mathrm{~h}$ with continuous removal of the liberated isopropyl alcohol as an azeotrope with benzene and estimated periodically to monitor the progress and completion of the reaction. When the distillate showed negligible presence of isopropyl alcohol, refluxing was stopped and the excess solvent was removed under reduced pressure to obtain a white sticky solid $(3.06 \mathrm{~g}, 99 \%)(1)$. The recrystallization from $2: 1$ mixture of $n$-hexane and dichloromethane at $-20^{\circ} \mathrm{C}$ yielded a white powdery solid. Yield $2.78 \mathrm{~g}(91 \%)$.

Adopting a similar procedure compounds (2) and (3) were also prepared repectively by the reactions of $\mathrm{Al}\left(\mathrm{OPr}^{\mathrm{i}}\right)_{3}$ with $\mathrm{HOCMe}_{2} \mathrm{CMe}_{2} \mathrm{OH}$ and $\mathrm{HOCMe}{ }_{2} \mathrm{CH}_{2} \mathrm{CH}_{2} \mathrm{CMe}_{2} \mathrm{OH}$.

\section{Preparation of $\mathrm{Al}\left(\mathrm{OCMe}_{2} \mathrm{CH}_{2} \mathrm{CHMeO}\right)_{2} \mathrm{Bu}_{2} \mathrm{Sn}\left(\mathrm{OPr}^{\mathrm{i}}\right)$ (4)}

The reaction mixture consisting of $\mathrm{Al}\left(\mathrm{OCMe} \mathrm{CH}_{2} \mathrm{CHMeO}\right)\left(\mathrm{OCMe}_{2} \mathrm{CH}_{2}-\mathrm{CHMeOH}\right)(1.77 \mathrm{~g}, 6.79 \mathrm{mmol})$ and $\mathrm{Bu}_{2} \mathrm{Sn}\left(\mathrm{OPr}^{\mathrm{i}}\right)_{2}(2.39 \mathrm{~g}, 6.80 \mathrm{mmol})$ in benzene $(\sim 30 \mathrm{ml})$ was refluxed for $\sim 4 \mathrm{~h}$. The liberated isopropyl alcohol $(0.40 \mathrm{~g})$ was fractionated out during the above-mentioned time and determined. After completion of the reaction, the volatile components from the solution were removed under reduced pressure to yield a white waxy solid $(3.63 \mathrm{~g})(4)$, which was distilled at $193{ }^{\circ} \mathrm{C} / 0.3 \mathrm{~mm}$ as an analytically pure product in quantitative yield $(3.23 \mathrm{~g}, 89 \%)$.

Derivatives (5), (6), (7), and (8) were also prepared in a manner similar to (4). Preparative, analytical, and 


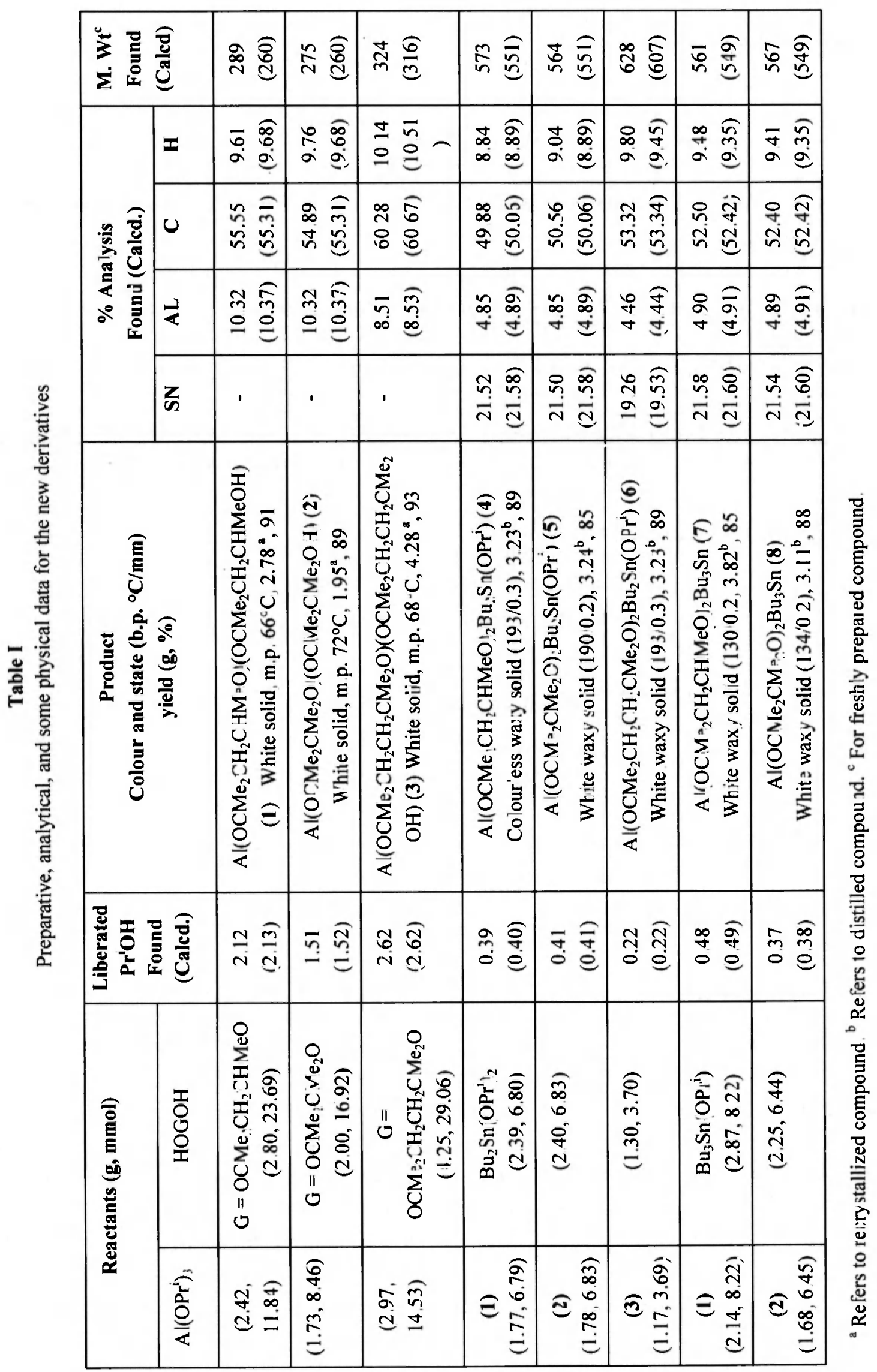


some physical data are listed in Table 1.

\section{RESULTS AND DISCUSSION}

Reactions of $\mathrm{Al}\left(\mathrm{OPr}^{\mathrm{i}}\right)_{3}$ with different glycols in 1:2 molar ratio in benzene afford soluble homometallic derivatives (eq (1)):

$$
\begin{aligned}
& \mathrm{Al}\left(\mathrm{OPr}^{\mathrm{i}}\right)_{3}+2 \mathrm{HOGOH} \frac{\mathrm{C}_{6} \mathrm{H}_{6}}{\text { reflux } \sim 6 \mathrm{~h}} \mathrm{Al}(\mathrm{OGO})(\mathrm{OGOH})+3 \mathrm{Pr}^{\mathrm{j} O H} \uparrow \\
& \mathrm{G}=\mathrm{CMe}_{2} \mathrm{CH}_{2} \mathrm{CHMe}(1), \mathrm{CMe}_{2} \mathrm{CMe}_{2}(2), \mathrm{CMe}_{2} \mathrm{CH}_{2} \mathrm{CH}_{2} \mathrm{CMe}_{2} \text { (3) }
\end{aligned}
$$

Reactions of (1), (2), or (3) with $\mathrm{Bu}_{2} \mathrm{Sn}\left(\mathrm{OPr}^{\mathrm{i}}\right)_{2}$ or $\mathrm{Bu}_{3} \mathrm{Sn}\left(\mathrm{OPr}^{\prime}\right)$ in 1:1 molar ratio in benzene under refluxing condition yield heterobimetallic derivatives (4), (5), (6) (eq. (2)), (7), and (8) (eq (3)):

$$
\begin{aligned}
& \mathrm{Al}(\mathrm{OGO})(\mathrm{OGOH})+\mathrm{Bu}_{2} \mathrm{Sn}\left(\mathrm{OPr}^{\mathrm{i}}\right)_{2} \frac{\mathrm{C}_{6} \mathrm{H}_{6}}{\text { reflux, } \sim 4 \mathrm{~h}} \\
& \mathrm{G}=\mathrm{CMe}_{2} \mathrm{CH}_{2} \mathrm{CHMe}(\mathbf{4}), \mathrm{CMe}_{2} \mathrm{CMe}_{2}(\mathbf{5}), \mathrm{CMe}_{2} \mathrm{CH}_{2} \mathrm{CH}_{2} \mathrm{CMe}_{2}(\mathbf{6}) \\
& \mathrm{Al}(\mathrm{OGO})(\mathrm{OGOH})+\mathrm{Bu}_{3} \mathrm{Sn}\left(\mathrm{OPr}^{i}\right) \frac{\mathrm{C}_{6} \mathrm{H}_{6}}{\mathrm{reflux}_{2} \sim 4 \mathrm{~h}} \\
& \mathrm{G}=\mathrm{CMe}_{2} \mathrm{CH}_{2} \mathrm{CHMe}(7), \mathrm{CMe}_{2} \mathrm{CMe}_{2}(8)
\end{aligned}
$$

All these new derivatives (1)-(8) are white solids, soluble in common organic solvents. The freshly prepared complexes (1)-(8) depict monomeric behaviour, but on aging homometallic derivatives (1)-(3) exhibit a tendency to association.

\section{Spectroscopic Studies}

\section{Infrared spectra}

Homometallic glycolates (1)-(3) (Figure 1, Table 11), exhibit broad absorption bands in the 3333-3233 $\mathrm{cm}^{-1}$ region due to the presence of intramolecular hydrogen-bonded $\mathrm{OH}$ group. Other structurally important infrared absorptions appear at 1048-1008 $v$ (C-O) and 653-647 $\mathrm{cm}^{-1} \vee(\mathrm{Al}-\mathrm{O})$. As expected, the heterobimetallic derivatives (4)-(8) show absence of band due to $\mathrm{OH}$ group and presence of absorption bands due to $v(\mathrm{C}-\mathrm{O})$ and $v(\mathrm{Al}-\mathrm{O})$ without considerable shifting. The derivatives (4)-(6) exhibit additional absorptions characteristic of the $\mathrm{Bu}_{2} \mathrm{SnO}_{2}$ moiety /12/ in the regions 729-680 ( $\mathrm{Sn}-\mathrm{CH}_{2}$ gauche), 666-640 (Sn$\mathrm{CH}_{2}$ trans $), 598-582 v(\mathrm{Sn}-\mathrm{O})+v(\mathrm{Sn}-\mathrm{C}), 526-516 v(\mathrm{Sn}-\mathrm{C})$ and 484-451 $v(\mathrm{Sn}-\mathrm{O}) \mathrm{cm}^{-1}$. The band appearing at $\sim 465 \pm 15 \mathrm{~cm}^{-1}$ may be attributed to $v(\mathrm{O} \rightarrow \mathrm{Sn}) / 13 /$. The presence of tributyltin moiety in derivatives $(7)$ and 


\begin{tabular}{|c|c|c|c|c|c|c|c|c|}
\hline$\stackrel{\omega}{\cong}$ & ' & . & ' & $\frac{2}{1}$ & 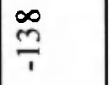 & $\frac{1}{2}$ & $\because$ & $\frac{1}{4}$ \\
\hline $\mathbb{\pi}_{\pi}^{\overline{4}}$ & $n$ & 3 & $\overline{6}$ & ชె & $\vec{r}$ & 8 & in & $\hat{n}$ \\
\hline$\equiv$ & 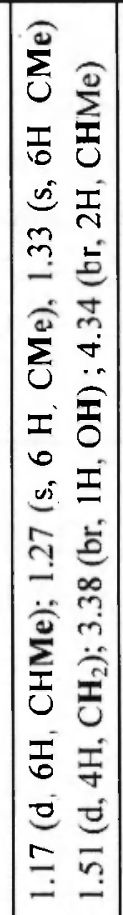 & 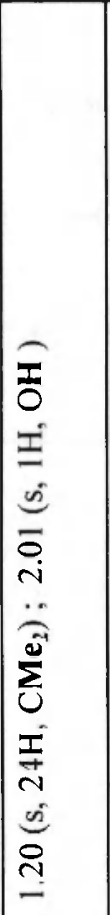 & 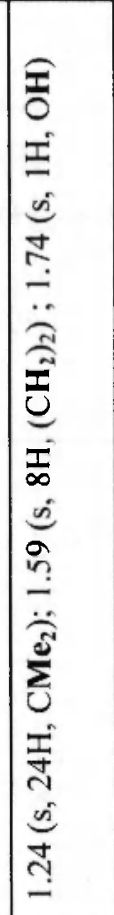 & 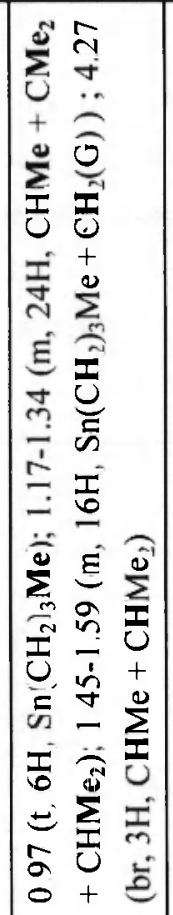 & 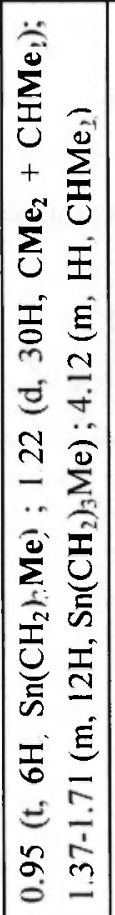 & 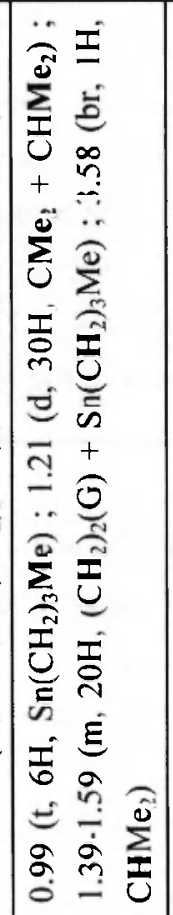 & 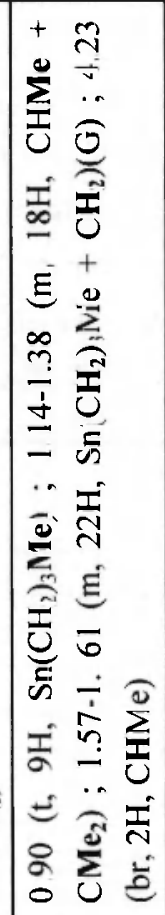 & 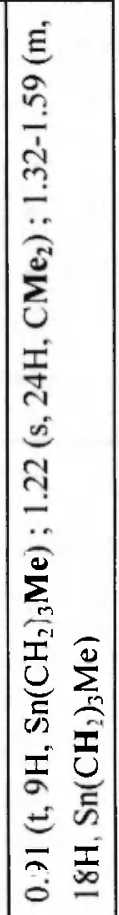 \\
\hline 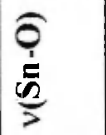 & ' & 1 & ' & 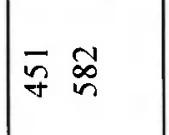 & 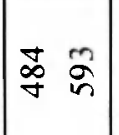 & 号串 & $\underset{\infty}{\infty} \infty$ & $\left(\begin{array}{ll} \\
\stackrel{\infty}{\rightarrow} & \bar{\infty} \\
\bullet\end{array}\right.$ \\
\hline 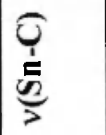 & ' & ' & ' & 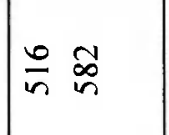 & 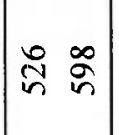 & $\frac{0}{n} \underset{n}{\infty}$ & $\stackrel{8}{n}$ & 号 \\
\hline $\int_{>}^{\frac{1}{3}} 0$ & 勇 & 离 & $\hat{\hat{b}}$ & 卓 & $\overline{\widehat{\sigma}}$ & 8 & $\overline{\hat{0}}$ & $\frac{7}{6}$ \\
\hline $\begin{array}{l}\widehat{\partial} \\
\frac{u}{>}\end{array}$ & $\bar{\Xi} \stackrel{\infty}{\circ}$ & 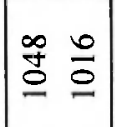 & 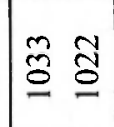 & 흥 & 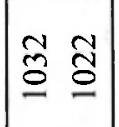 & $\underline{\hat{\sigma}} \bar{\Xi}$ & $\underline{\tilde{\sigma}} \stackrel{0}{\circ}$ & $\underline{\sigma} \stackrel{0}{0}$ \\
\hline$\frac{2}{\frac{2}{2}}$ & ' & ' & ' & $\stackrel{\infty}{=}$ & $\stackrel{\otimes}{=} \underset{\underline{O}}{=}$ & $\stackrel{g}{\Xi}$ & ' & ' \\
\hline$\widehat{\widehat{̃}}$ & 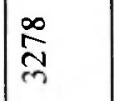 & $\hat{\widetilde{N}}$ & $\hat{m}$ & ' & I. & ' & ' & ' \\
\hline 产 & 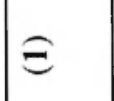 & (2) & (ొ) & $\widehat{\Theta}$ & 6 & e & $E$ & $\infty$ \\
\hline
\end{tabular}


(8) is indicated by the appearance of bands at $540 \pm 6$ and 500 assignable to $v(\mathrm{Sn}-\mathrm{C})$ stretching vibration and at $580 \pm 2$ and $483 \pm 1 \mathrm{~cm}^{-1}$ due to $v(\mathrm{Sn}-\mathrm{O})$. These observations regarding derivatives (7) and (8) can be rationalized in terms of the trans- $\mathrm{Bu}_{3} \mathrm{SnO}_{2}$ structure [14] as depicted in Figure 2. Derivatives (4), (5), and (6) also exhibit characteristic absorptions for isopropoxy group(s) at $1175 \pm 5$ and $1135 \pm 10 \mathrm{~cm}^{-1}$.

\section{${ }^{\prime} \mathrm{H}$ NMR spectra}

Homometallic derivatives (1)-(3) (Table II) exhibit a broad peak in the $\delta$ 1.74-3.38 region due to the residual $\mathrm{OH}$ group in addition to the signals characteristic of the glycolate moieties : $\delta 1.17-1.33\left(\mathrm{CMe}_{2}\right)$, 1.51-1.59 ( $\left.\mathrm{CH}_{2}\right), 4.34$ (CHMe). The heterobimetallic derivatives (4)-(6) show a doublet and a multiplet for methyl and methine protons of the isopropoxy groups at $\delta 1.17-1.34$ and $3.58-4.27$, respectively along with signals due to glycolate moieties at $\delta$ 1.17-1.34 $\left(\mathrm{CMe}_{2}\right), 1.39-1.59\left(\mathrm{CH}_{2}\right), 4.27(\mathrm{CHMe})$. A triplet due to $\mathrm{Me}\left(\mathrm{CH}_{2}\right)_{3} \mathrm{Sn}$ protons in (4)-(8) appears at $\delta 0.97 \pm 0.02$.

\section{${ }^{27}$ Al NMR spectra}

The presence of tetracoordinated aluminium/15/ (Figures 1 and 2) in derivatives(1), (2), (3), (4), (5), (6), (7), and (8) is supported by the appearance of broad $\left(\omega_{1 / 2}=\sim 157.32 \mathrm{~Hz}\right){ }^{27} \mathrm{Al} \mathrm{NMR}$ signals at $\delta 55,63,61$, $62,74,60,50$, and 53 , respectively.

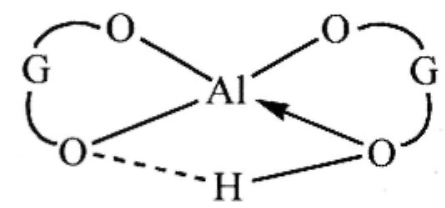

$$
\text { (1) }\left(\mathrm{G}=\mathrm{CMe}_{2} \mathrm{CH}_{2} \mathrm{CHMe}\right) \text {, (2) }\left(\mathrm{G}=\mathrm{CMe}_{2} \mathrm{CMe}_{2}\right) \text {, and }
$$

(3) $\left(\mathrm{G}=\mathrm{CMe}_{2} \mathrm{CH}_{2} \mathrm{CH}_{2} \mathrm{CMe}_{2}\right)$.

Fig. 1: Suggested structure for homometallic derivatives

\section{${ }^{1 / 9}$ Sn NMR spectra}

The appearance of sharp ${ }^{119}$ Sn NMR signals at $\delta-179,-138,-142,-12$, and -14 , respectively for the derivatives (4), (5) (6), (7), and (8) is consistent with five-coordinate/16-17/ organotin (IV) derivatives (Figure 2).

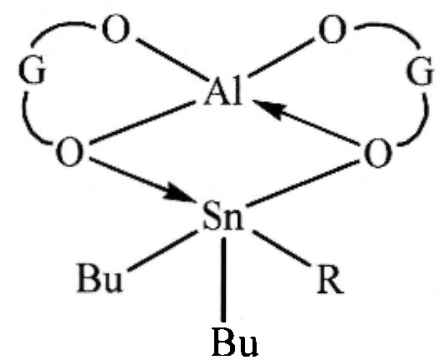

(4) $\left(\mathrm{R}=\mathrm{OPr}, \mathrm{G}=\mathrm{CMe}_{2} \mathrm{CH}_{2} \mathrm{CHMe}\right)$, (5) $\left(\mathrm{R}=\mathrm{OPr}^{\mathrm{i}}, \mathrm{G}=\mathrm{CMe}_{2} \mathrm{CMe}_{2}\right)$, (6) $(\mathrm{R}=\mathrm{OPr}, \mathrm{G}=$ $\left.\mathrm{CMe}_{2} \mathrm{CH}_{2} \mathrm{CH}_{2} \mathrm{CMe}_{2}\right)$, (7) ( $\left.\mathrm{R}=\mathrm{Bu}, \mathrm{G}=\mathrm{CMe}_{2} \mathrm{CH}_{2} \mathrm{CHMe}\right)$, and (8) $\left(\mathrm{R}=\mathrm{Bu}, \mathrm{G}=\mathrm{CMe}_{2} \mathrm{CMe}_{2}\right)$.

Fig. 2 : Suggested structure for heterobimetallic derivatives 


\section{ACKNOWLEDGEMENTS}

N.B.S. is grateful to the State Government of Rajasthan and Department of Chemistry, University of Rajasthan, Jaipur for a Fellowship under Special Assistance Programme. A.S. is grateful to the U.G.C., New Delhi, for an Emeritus Scientist Grant. The Senior Scientist Grant by the INSA, New Delhi to (late) R.C.M. is gratefully acknowledged. Authors are also thankful to Mr. Suman Gupta for recording the NMR spectra.

\section{REFERENCES}

1. R.C. Mehrotra and A. Singh, Prog. Inorg. Chem., 46, 239 (1997).

2. D.C. Bradley, R.C. Mehrotra, I.P. Rothwell and A. Singh, Alkoxo and Aryloxo Derivatives of Metals, Academic Press, London, 2001.

3. A. Singh and R.C. Mehrotra, Coord. Chem. Rev., 248, 101 (2004).

4. Y. Takahashi, K. Niwa, K. Kobayashi and M. Matsuki, Yagyo Kyokaishi, 95, 942 (1987); Chem. Abstr., 107, 203776 h (1987).

5. D.D. Perrin, W.L.F. Armarego and D.R. Perrin, Purification of Laboratory Chemicals, $3^{\text {rd }}$ ed., Pergamon Press, Oxford, U.K., 1986.

6. R.C. Mehrotra and B.P. Bachlas, J. Organomet. Chem., 22, 121 (1970).

7. L.M. Brown and K.S. Mazdiyasni, Inorg. Chem., 9, 2783 (1970).

8. C. Adams and J.R. Nichollas, Analyst, 50, 2 (1929).

9. D.C. Bradley, F.M.A. Halim and W. Wardlaw, J. Chem. Soc., 3450 (1950).

10. R.C. Mehrotra, J. Indian Chem. Soc., 30, 585 (1953).

11. A.l. Vogel, A Text Book of Quantitative Chemical Analysis, $5^{\text {th }}$ ed. Longman, London, 1989.

12. P. Rupani, A. Singh, A.K. Rai and R.C. Mehrotra, J. Organomet. Chem., 185, 209 (1980).

13. H.C. Clark and R.G. Goel, J. Organomet. Chem., 7, 263 (1967).

14. P.G. Harrison and J.A. Richards, J. Organomet. Chem., 185, 9 (1980).

15. M. Sharma, A. Singh and R.C. Mehrotra, Synth. React. Inorg. Met.-Org. Chem., 32, 1233 (2002).

16. V.K. Jain, J. Mason, B.S. Saraswat and R.C. Mehrotra, Polyhedron, 4, 2089 (1985).

17. K. Sharma, M. Sharma, A. Singh and R.C. Mehrotra, Main Group Met. Chem., 26, 131 (2003). 


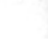

